\title{
Formas atuais de bichos muito antigos - a atualização do conto popular em "Como ataca a sucuri", de Guimarães Rosa
}

\author{
Claudia Lorena Vouto Fonseca ${ }^{*}$
}

\section{RESUMO}

Este estudo discute algumas questões relativas à gênese do Conto, além de discutir a relação de oposição entre Forma simples x Forma artística. Tomamos Guimarães Rosa como paradigma, pois o autor resgata, em sua obra, aspectos referentes às formas ancestrais de contar, atualizandoos. Como contista, a partir do aproveitamento dos temas e das formas populares, características das narrativas de tradição oral, que utilizam com frequência o elemento maravilhoso, o autor tece seu próprio contar. Seu feitio, porém, não se assemelha ao dos compiladores, mercê de um trabalho minucioso e artesanal com a palavra, o qual acaba por atribuir à tessitura do texto uma especificidade que intriga, encanta e convida ao jogo. Estudamos essa atualização do conto popular de tradição oral na obra de Guimarães Rosa à luz da Metalinguística bakhtiniana, utilizando o conto "Como ataca a sucuri”, de Tutaméia, como exemplo desse fato, pois cremos que sua teoria ajuda a esclarecer os aspectos da obra rosiana que dizem respeito ao discurso. A direção que tomamos em nossa análise diz respeito, justamente, ao discurso na obra do autor mineiro, sobretudo às formas de citação desse discurso, fator relevante em seu fazer literário.

Palavras-chave: Conto. Oralidade. Guimarães Rosa. Filosofia da Linguagem.

Ao longo do processo de evolução por que passou a forma literária que conhecemos por "conto", fica evidente que cada vez mais este se distanciou de suas origens: a oralidade, a essência popular, que agrega o maravilhoso, configurando o que chamamos de moderno conto literário, como o concebeu Edgar Allan Poe, estabelecendo suas bases, provavelmente de maneira definitiva, pois não só fez seguidores, como se transformou em parâmetro e referência para aqueles que a partir dele teorizaram sobre o conto ou, mesmo, criaram dentro dessa forma. A sofisticação que adquire a forma com Poe, depois dele fez escola e evoluiu, cada vez mais elaborada, eternizando nomes como o de Guy de Maupassant, Machado de Assis e Anton Tchekov, este, responsável por uma nova tendência da forma, que por sua vez também teve adeptos, proporcionando sua atualização, apontando para

* Faculdade de Letras da Universidade Federal de Pelotas - UFPEL. 
a contemporaneidade, em que as fronteiras entre os tipos de textos literários estão mais diluídas, com o conto desdobrando-se em múltiplas formas, inclusive com a recuperação da tradição oral.

No entanto, se percebemos que a contemporaneidade tem buscado resgatar o que de essencial constitui o conto, não apenas reservando um lugar de destaque a essa forma tão maleável, mas operando um movimento dirigido à atualização das formas do contar, podemos dizer que, ainda hoje, estabelecer definições precisas a respeito do que é exatamente o conto, não é tarefa simples. No que diz respeito às suas origens, sabemos que, independentemente de algumas controvérsias, concordam os estudiosos que o conto tem origem nas narrativas orais: o conto, como o conhecemos, começa como oralidade compilada. A partir da Idade Média, passa pela novela toscana, verdadeiro ponto nevrálgico, a qual dá origem ao conto literário, embora tenha pouco salientada sua importância. Passa, também, pelos contos populares, nos moldes dos irmãos Grimm, e pelos fablieux, até chegar ao moderno conto literário, nos moldes de Poe.

São muitos os teóricos que se dedicam a investigar a gênese da forma conto, via de regra, boa parte desses estudiosos acrescenta algum dado novo ou salienta características pouco ou mal consideradas. Podemos destacar alguns deles, como, por exemplo, Luis Barrera Linares (1997) que, aludindo desde Meneses a Borges, passando por Cortázar, entre outros, formula uma espécie de definição, provisória, segundo ele, mas não destituída de um caráter de síntese, diríamos nós, tentando aproveitar o que de positivo e afiançável cada um desses autores acrescenta a propósito:

Partiendo de una definición muy provisional, y ampliando la idea recogida en Meneses (1966), digamos que el cuento literario (el texto) es indudablemente una clase de mensaje narrativo breve, elaborado con la intención muy específica (por parte del autor) de generar un efecto o impresión momentánea e impactante en el destinatario (el lector) y cuya composición lingüística pareciera restringida por la escogencia focalizadora de uno solo tema (un hecho, un ámbito o un personaje, según Balza), narrado a partir de una serie de macroproposiciones únicas (Van Dijk, (1983), no vinculadas semánticamente con ningún otro texto narrativo adherente o coexistente, lo que a su vez lo reviste de una relativa autonomía semántica y formal. (LINARES, 1997, p. 34).

Podemos citar, ainda, Michèle Simonsen (1987), que teoriza sobre o conto popular, localiza sua origem já na Antiguidade, na forma oral, e destaca que, dentre os diversos gêneros de narrativas populares, o conto é o único que "não é verdade", 
mas sim ficção. A autora também ensaia uma definição: "O conto é, pois, um relato em prosa de acontecimentos fictícios e dados como tais, feito com a finalidade de divertimento" (SIMONSEN, 1987, p. 6 - destaques da autora). Não esquecer que conto, aqui, é o conto popular, sobre o qual discorre também André Jolles (1976), denominando-o "forma simples", contrapondo-o à forma que ele chama de "artística", o conto literário. Jean-Pierre Aubrit (1997) está entre os que fazem histórico; Brander Matthews (1997) entre os que retomam Poe, a sua conveniência; Julio Cortazar (1993) retrata o contista como um sujeito por vezes "possuído" pela sua matéria, destacando elementos importantes, como a questão do tema do conto ou, interessantes, como o fato de diferençar romance e conto, equiparando-os ao cinema e à fotografia, respectivamente. Já Mário de Andrade está entre os que simplificam: sua definição de conto é conhecida: "sempre será conto aquilo que seu autor batizou com o nome de conto" (ANDRADE, 1972, p. 5). E, ainda, Herman Lima (1971), contribui quando identifica as duas formas do moderno conto universal: aquela que deriva de Maupassant e a representada por Tchekov. Assim, também, contribui Ricardo Piglia (1991), com suas teorias, que não derrubam nenhuma outra teoria do conto, mas tratam de outro aspecto, o que se configura em um acréscimo a elas. Seus estudos explicam ou abordam o caráter ambíguo do conto, descobrindo algo que escapou aos mestres. Todos, ou quase todos os contos se enquadram, podem ser encaixados em suas teorias, que não são propriamente revolucionárias, não modificam nem definem a forma do conto, mas atualizam-na.

\section{O conto popular: uma forma simples?}

Mas, se alguns se dedicam a estabelecer definições a partir, principalmente, de estudos anteriores, outros visam a estabelecer teorias e outros, ainda, teorizam sem tentar fixar parâmetros, fixando-os, a sua revelia. Em relação ao último aspecto, falamos de Achim Von Arnim e Jacob Grimm que, na primeira metade do século XIX, protagonizaram uma polêmica epistolar que rendeu, talvez, uma das melhores contribuições para a definição de algumas vertentes do conto contemporâneo, bem como a constatação do caráter plural dessa forma. André Jolles, tentando estabelecer os critérios do conto como forma simples - e "conto", nesse caso, é o conto popular, o que chamamos fábulas ou contos de fadas -, contrapondo-o às formas artísticas ${ }^{1}$, é quem traz o pensamento desses dois contistas e teóricos alemães do Romantismo para o centro do debate.

1 Jolles, quando alude ao termo "novela", refere-se à "novela toscana", em coletânea ou em publicação isolada, matriz do conto literário (CF. JOLLES, 1976). 
A cisão entre o conto popular e o conto literário talvez tenha começado com a oposição entre Arnim e Grimm. Foi nesse momento, provavelmente, que ele adquiriu dupla identidade. Para Grimm existe uma distinção entre poesia da natureza (criação espontânea, que brota do coração do todo - e que Jolles chama de forma simples) e poesia artística (elaboração, produto da alma individual o que Jolles chama de forma artística); para Arnim não existe essa distinção, literariamente só existe uma forma e esta é uma forma artística, pois é atualizada a partir da matriz popular. Os contos que são compilados diretamente da tradição oral seriam uma elaboração, uma atualização destes.

De certo modo, Arnim e sua teoria são mais "modernos" que Poe e aqueles que o seguiram, pois não dita preceitos rígidos de como fazer, nem se põe a divagar sobre a questão, mas prevê a atualização que o conto efetivamente sofreu desde a origem. Sua teoria é mais coerente, moderna, aberta e visionária. Para ele, a ordem é aperfeiçoar a partir de tudo, inclusive a partir dos antigos. Jolles diz que é no incentivo à "invenção" que Arnim vê o significado do conto e que, para este, "as coisas novas existem, são o essencial, é necessário empregar todos os meios para animá-las e aperfeiçoá-las - sobretudo por meio da tradição, das coisas antigas, do fundo popular" (JOLLES, 1976, p. 186). Ora, nada mais atual. Grimm acrescenta à teoria, detectando que, no compilado, por mais que não se pretenda, resta uma essência, um fundo, a marca das sucessivas narrações, que permanece, também, ao cabo de sucessivas atualizações. Na verdade, Arnim e Grimm se complementam, no fundo dizem praticamente a mesma coisa, mesmo que não o percebam. Sua diferença de pontos de vista acabou por constituir-se em valiosa base teórica para uma teoria do conto contemporâneo, que hoje também incorpora a oralidade, associando literário ao popular, e que não descarta Poe, fazendo dele exemplo de atualização e matriz, ainda.

Reforçando a teoria de Arnim, encontramos um outro contista alemão, este surgido ainda no século XVIII e, portanto, antecessor daquele e de Grimm: Christoph Martin Wieland que, também citado por Jolles, dá mostra ainda maior de atualidade. Jolles diz que, segundo esse autor,

o conto é uma forma de arte em que se reúnem e podem ser satisfeitas em conjunto duas tendências opostas da natureza humana, que são a tendência para o maravilhoso e o amor ao verdadeiro e ao natural. Sendo ambas as tendências inatas na humanidade, encontraremos por toda a parte os contos, alguns deles muito antigos. Entretanto nessa Forma artística, o que importa é levá-los a uma justa relação recíproca; se esta faltar, o conto perde em atrativo e valor. Quanto ao estabelecimento da relação recíproca, é questão de gosto, é questão do artista. (JOLLES, 1976, p. 91). 
Jolles reproduz, ainda, as palavras do próprio Wieland: "As produções desta espécie devem ser obras de gosto ou não valem nada. Os contos da velha ama, contados em linguagem de ama, podem propagar-se pela tradição oral; não precisam ser impressos" (WIELAND apud JOLLES, 1976, p. 191). Como podemos perceber, Wieland destaca o trabalho do artista, a quem é permitido beber nas fontes da tradição oral, transformando-a em arte literária, pois o conto pode ser "invenção" e estar ligado à tradição popular e à oralidade, sendo trabalho explícito de criação.

André Jolles salienta ser o conto uma forma que tem nomes diferentes dependendo do idioma, mas que deve sua definição basicamente àquilo que os irmãos Grimm tinham como conto. $\mathrm{O}$ autor concorda com Grimm principalmente em relação à diferença entre as formas do conto e a sua essência, mas discorda quanto às formas espontânea e elaborada do conto pertencerem, respectivamente, ao passado e ao presente da forma; concorda em parte, também, com Arnim e Wieland. Contrapondo o conto (popular) à novela (conto literário, descendente da novela original), Jolles afirma que existe uma diferença formal básica:

a forma novela pode ser aplicada a uma parcela do universo e de cada vez essa parcela far-se-á representar como novela (...). Mas desde que se procure aplicar igualmente essa forma [o conto] ao universo, sente-se que é impossível: não é que os fatos tenham que ser forçosamente maravilhosos no conto, ao passo que não o são no universo; trata-se, antes, de que os fatos, tal como os encontramos no Conto, só podem ser concebidos no Conto. Numa palavra: pode aplicar-se o universo ao conto e não o conto ao universo. (JOLLES, 1976, p. 193).

A Novela e o Conto são igualmente Formas; entretanto as leis formativas da novela são tais que ela pode dar uma fisionomia coerente a todo o incidente narrado, seja real ou inventado, porque tem como característica específica ser impressionante; as leis de formação do conto são tais que, sempre que ele é transportado para o universo, este transforma-se de acordo com um principio que só rege esta Forma e só é determinante para ela. (JOLLES, 1976, p. 194 - destaques meus).

André Jolles pretende, além de estabelecer a diferença, nomeá-la, distinguindo entre as formas do conto, classificando-as como simples e artística, embora admita que não irá aprofundar a discussão acerca da atualização da forma simples naquele estudo: 
Haveria todo um estudo a fazer, e da mais alta importância para a teoria literária, sobre o que pode ocorrer em geral e o que ocorre em particular sempre que determinada Forma Simples se encontra com uma Forma artística; mas esse estudo, que verificaria o que pode resultar de tais cruzamentos, não pode ser levado a cabo neste volume. Podemos apenas dizer aqui que, em tal caso a Forma Simples rejeita semelhante espécie de acasalamento, opõe-se a que a modelem nesse sentido e pretende manter-se ela própria. (JOLLES, 1976, p. 196).

Diríamos que não é exatamente o "acasalamento" que rejeita a forma simples em relação à forma artística, mas sim a "fusão" total com essa forma. O que constatamos é que existe uma diferença, mas entre duas formas artísticas, pois ambas são formas elaboradas. $\mathrm{O}$ conto, em sua forma literária, sempre foi forma artística, porque sofre atualizações e trabalho formal. A forma simples seria o conto em sua forma oral ou, no máximo, a forma oral compilada, nos moldes do que empreendeu Câmara Cascudo, por exemplo. Também poderia ser chamada de forma simples, talvez, a essência, o fundo popular que se identifica mesmo na forma literária. Esta, é certo, pode se apropriar da forma simples e atualizá-la, já o contrário, não é possível.

O conto contemporâneo não é necessariamente debitário direto do conto literário dos mestres, embora deva a esses, mas pode retornar, também, ao conto popular e ser muito mais próximo deste, gozando de uma pluralidade que, ao mesmo tempo em que abrange o mundo e o homem de hoje, torna mais difícil a apreensão da essência da forma. Diríamos que os mestres são herdeiros da "novela toscana" e que os modernos podem ser, também, se assim o quiserem, herdeiros do conto popular, agora literarizado ou, indiscutivelmente, artístico, graças às lições dos mestres.

\section{A forma conto e Guimarães Rosa}

Certamente André Jolles, que publica seu estudo sobre as formas simples em 1930, não teve contato com a obra de Guimarães Rosa, pois, se tivesse tido essa oportunidade, talvez revisse algumas de suas posições, já que o autor mineiro aí está para comprovar o que foi afirmado no item anterior. Para Guimarães, e para o conto contemporâneo em geral, podemos nos valer do que diz Arnim: “a tendência para constituir e continuar uma obra é mais forte no homem que todos os seus projetos e simplesmente impossível de erradicar [...] O fio jamais se quebra; 
é, necessariamente, uma outra textura que transparece" (JOLLES, 1976, p. 187), e do que pensa Wieland, nas palavras de Jolles, que não compartilha da mesma opinião:

tanto a novela quanto o conto são formas artísticas literárias - a primeira, expressão de uma única tendência humana, a que busca o verdadeiro e o natural; e o segundo um amálgama de duas tendências humanas, aquela que busca o verdadeiro e o natural e a que corresponde ao anseio de maravilhoso. (JOLLES, 1976, p. 193).

O conto de Guimarães Rosa é, justamente, amálgama das duas formas curiosamente deixando que se distingam suas fronteiras -, mesmo que sofra a influência daqueles que o precederam, pois, em sua obra, encontramos contos à maneira de Poe, de Maupassant, de Machado, ou de Tchekov, entre outros, mesclando inclusive as tendências. Porém, em sua maioria, sobressai uma essência popular, uma ancestralidade, um elo muito forte com a oralidade, com a tradição oral, confirmando Arnim, Wieland e, mesmo, Jolles, já que se aplicam ao universo rosiano suas palavras a respeito do conto, quando estabelece diferenças entre essa forma e a novela, dizendo que, ao contrário desta, a forma conto

não se empenha mais em narrar um incidente impressionante, pois salta de incidente em incidente para descrever todo um acontecimento que não se encerra em si mesmo de maneira determinada, o que só ocorre no remate final ou desfecho da narrativa; em segundo lugar, tampouco se empenha mais em representar tal acontecimento de modo a dar-nos a impressão de um acontecimento real, preferindo trabalhar constantemente no plano do maravilhoso. (JOLLES, 1976, p. 192).

[...] no Conto, que enfrenta abertamente o universo e o absorve, o universo conserva, pelo contrário, apesar dessa transformação, sua mobilidade sua generalidade e - o que lhe dá a característica de ser novo de cada vez - sua pluralidade. (JOLLES, 1976, p. 194/195destaques meus).

André Jolles tem, nessa sua tentativa de estabelecer a diferença entre forma simples e forma artística, apesar de não estarmos totalmente de acordo com esse autor em relação a tal divisão, outras posições que nos servem adequadamente para a análise da obra, mais especificamente, dos contos de Guimarães Rosa. Uma delas é a diferença entre a linguagem dessas formas (que poderia ser aplicada aos outros elementos da narrativa), outra é a questão relacionada àquilo que ele chama de "disposição mental". Jolles afirma que a linguagem, 
na Forma artística, só pode, enfim, encontrar a sua realização definitiva mediante a ação de um poeta, entendendo-se o "poeta", evidentemente, não como a força criadora mas como a força realizadora. $\mathrm{Na}$ Forma simples, pelo contrário, a linguagem permanece fluida, aberta, dotada de mobilidade e de capacidade de renovação constante. (JOLLES, 1976, p. 195 - destaques do autor).

Além disso, assim como na linguagem, personagens lugares e incidentes, na forma simples, conservariam seu caráter fluido, genérico, sempre renovado. A atualização da forma simples apoiar-se-ia sempre nesses aspectos, inerentes à própria forma. Já na atualização da forma artística, a obra fechada se empenharia de novo em ser sólida, peculiar e única. A forma simples, segundo Jolles, rejeitaria o acasalamento com uma forma artística, pois que tal fato levaria a sua fixação definitiva, transformando-se, por conseguinte, em forma artística.

Guimarães Rosa contraria essa tese. Sua obra, além de recuperar a tradição oral, é construída pelo trabalho com a linguagem, trabalho formal, mesmo artesanal que, no entanto, não perde seu caráter fluido, aberto, nem sua mobilidade ou capacidade de renovação constante em sua atualização da forma. Logo, o acasalamento entre as duas formas pode efetivar-se - o que não pode ocorrer é a sua fusão -, pois são formas específicas de uma mesma categoria, artísticas ambas, sendo que os resultados decorrentes dessa união, pelo menos nesse caso em especial, não poderiam ter sido mais bem-sucedidos.

$\mathrm{O}$ outro aspecto abordado por André Jolles, que nos interessa destacar, pois que está explícito na obra de Guimarães Rosa - incorporando-se por vezes à própria temática -, é aquele relacionado ao princípio da disposição mental do conto e das demais formas simples. Segundo sua tese, o universo transformase, no conto, de acordo com esse princípio, que somente rege e determina essa forma. A disposição mental do conto está relacionada à questão da moralidade ou, mais especificamente, ao caráter moralizante da narrativa. Característica típica do conto popular, na acepção dos irmãos Grimm e seguidores, a "moral da história", estamos cientes, está associada de maneira indelével a essa forma, explícita ou implicitamente. Jolles cita o exemplo de Perrault e sua obra intitulada "Contes du temps passé avec de Moralités", e sintetiza o raciocínio. Nos contos, "a virtude é sempre recompensada e o vício punido” (PERRAULT apud JOLLES, 1976, p. 198), mesmo que as personagens e as aventuras do conto não nos propiciem a impressão de serem verdadeiramente morais, pois tudo isso passa também pela subjetividade: bondade e justiça passam pelo nosso "juízo sentimental absoluto". De qualquer modo, segundo o autor, é inegável que esses aspectos 
nos proporcionem certa satisfação porque (menção a Wieland) "satisfazem, ao mesmo tempo, o nosso pendor para o maravilhoso e o nosso amor ao natural e ao verdadeiro" (JOLLES, 1976, p. 198) e, sobretudo, "porque as coisas se passam nessas histórias como gostaríamos que acontecessem no universo, como deveriam acontecer" (JOLLES, 1976, p. 198 - destaques do autor). Satisfazem aquilo que Jolles denomina nossa "moral ingênua", ou seja, a ideia de que tudo deva passar-se no universo de acordo com nossa expectativa é fundamental para a forma do conto, é a sua disposição mental específica. E mais, o conto se opõe e recusa o universo da realidade que contraria a moral ingênua, que ele chama de "trágico", adotando um outro universo paralelo, em que o trágico é, ao mesmo tempo, proposto e abolido, satisfazendo-nos plenamente no tocante a esse aspecto.

Em "Uma estória de amor (A festa de Manuelzão)", uma das novelas de Corpo de baile (1960), Guimarães Rosa trata, metaliterariamente, do tema em questão. A "contadora de estórias" Joana Xaviel, ao final de um de seus contares - protagonizado por Destemida, uma voluntariosa e impiedosa mulher -, ao contrário do habitual, deixa insatisfeitos seus ouvintes:

A estória se acabava aí, de-repentemente, com o mal não tendo castigo, a Destemida graduada de rica, subida por si, na vantagem, às triunfâncias. Todos que ouviam, estranhavam muito: estória desigual das outras, danada de diversa. Mas essa estória estava errada, não era tôda! Ah, ela tinha de ter outra parte - faltava a segunda parte? A Joana Xaviel dizia que não, que assim era que sabia, não havia doutra maneira. Mentira dela? A ver que sabia o resto, mas se esquecendo, escondendo. Mas - uma segunda parte, o final - tinha de ter! Um dia, se apertasse com a Joana Xaviel, à brava, agatanhal, e ela teria que discorrer o faltante. Ou, então, por aí fundo, todo longe, pelos ôcos e veredas do mundo Gerais, caçando - para se indagar - cada uma das velhas pessôas que conservavam as estórias. Quem inventou o formado, quem por tão primeiro descobriu o vulto de idéia das estórias? Mas, ainda que nem não se achasse mais a outra parte, a gente podia, carecia de nela acreditar, mesmo assim sem ouvir, sem ver, sem saber. Só essa parte é que era importante. (ROSA, 1960, p. 105/106).

O conto é incompreensível sem o maravilhoso, e não precisam os teóricos da literatura afirmá-lo, pois de forma mesmo que intuitiva sabemos. O que talvez poucos saibam é que "o prodígio do maravilhoso é a única possibilidade que se tem de estarmos seguros de que deixou de existir a imoralidade da realidade." (JOLLES, 1976, p. 202). No conto, o maravilhoso não é maravilhoso, é natural. Guimarães prova a atualidade de Arnim e Wieland que, antes mesmo de Poe, já 
anteviam o futuro da forma. A forma do conto em Guimarães Rosa é a do conto como o concebiam esses dois autores, mais a sua atualização, a qual se dá, sobretudo, pelo uso incomum e muito particular que o autor faz da linguagem. É no nível da linguagem que se dão os acontecimentos em grande parte da obra do autor mineiro, assim como é no nível de um tempo indefinido que a ação transcorre, um tempo suspenso entre o passado e um presente impreciso, um "passado presentificado", fortemente marcado pelo medievo. Esse elemento o aproxima dos primórdios da narrativa de tradição oral. O universo do conto rosiano é caracterizado pela presença "habitual e natural" de contadores de história, cavaleiros, príncipes, princesas, malfeitores, sugestões de metamorfose, encantamentos, crendices, objetos mágicos, situações inusitadas e inexplicáveis e, sobretudo, pela epifania, consequência dessa atmosfera medieval, carregada de religiosidade e misticismo.

Todos esses aspectos, transportados para o universo rosiano, demonstram que Guimarães Rosa é um autêntico contista. Mas não há como negar, pois está evidente, em sua obra, o trabalho formal, sobretudo o trabalho com a língua. Poderíamos falar em forma não-artística, ao nos referirmos à obra de Guimarães? De modo algum, não poderíamos. Além do que, mesmo lidando com uma forma popular, como o conto nos moldes de Grimm e, mesmo, em moldes anteriores a este, reportando-se aos temas medievais, o autor mineiro não é exatamente o que poderíamos chamar de contista popular, na acepção popularesca do termo. Não consta que sua obra seja tão acessível quanto se poderia supor, em se tratando de autor tão ligado a temas da tradição oral. Portanto, o conto, principalmente na contemporaneidade, é forma artística. Guimarães Rosa não é caso isolado.

\section{Como ataca a sucuri}

“Como ataca a sucuri” encontra-se, em Tutaméia (1967), na 1ª parte da obra, referente ao $1^{\circ}$ prefácio. O conto, em sua extensão, é bastante curto: apenas três páginas. Seu enredo pode ser considerado simples: um homem, Drepes, vindo de um centro urbano, chega ao interior supostamente com o intuito de pescar, mas está, provavelmente, perdido. Acaba abrigado na casa de um morador da localidade, Pajão, sujeito primitivo, estranho, tanto do ponto de vista físico quanto moral, digamos. O forasteiro, a seu pedido, é levado a um local de pesca, lugar perigoso, e escuta o som do que supõe ser a cobra-grande. ${ }^{2}$ A partir daí indaga

2 Sabemos das apropriações que a autor faz dos textos ligados às formas populares de contar. Há uma lenda do Norte do país, intitulada "Cobra Norato", que nos parece ter servido de inspiração ao autor, que a estaria atualizando. 
a seu hospedeiro sobre os hábitos da sucuri. Trava-se, desde o início, de um jogo de poder, velado, que se intensifica a partir da intenção do recém-chegado de compreender o universo que o sertanejo tem como seu e não do outro. Há, também, uma certa violência latente. Esse jogo perdura até o desfecho, quando a sucuri, que perpassou toda a narrativa no jogo da linguagem, aparece morta por Drepes, o qual, após o fato, vai embora, deixando Pajão com o couro do réptil.

São duas as personagens que influirão na evolução da narrativa: Drepes e Pajão. Outras personagens se fazem presentes, porém são secundárias, familiares do sertanejo que, a exemplo deste, compartilham de sua visão de mundo, têm comportamento análogo ao do seu líder. A ação se passa no transcurso de dois dias e uma noite, no sertão mineiro, mais especificamente em um local denominado Brejos da Sumiquara. No que tange à narração, o que observamos é uma situação de diálogo no mínimo inusitada, com a alternância da voz narrativa. Essas vozes, em determinados momentos, se confundem. A primeira frase já dá uma ideia da ambiguidade que se estabelecerá no decorrer da narrativa:

O homem queria ir pescar? Pajão então levava-o ao certo lugar, poço bom, fundo, pesqueiro. O resto virava com Deus... Inda que penoso o caminhar, dava gosto guiar um excomungado, assim, hum, a mais distante, no fechado da brenha. (ROSA, 1967, p. 31).

O enunciado, em terceira pessoa, está carregado de marcas lexicais que denotam ser um discurso pertencente a uma pessoa sem grande erudição, o que pode levar a crer, a princípio, tratar-se de um narrador natural de uma determinada comunidade linguística, mas não necessariamente Pajão. No entanto, são evidentes as muitas marcas de oralidade, como elipses, abreviações, marcas de emoção e afetividade - características do discurso direto; uma apreciação ou juízo de valor; impressões, sentimentos, etc. Por vezes, parece que o narrador é personagem e se refere a si mesmo em terceira pessoa, já que ele tem um nome, ao contrário daquele a quem se refere, que é chamado de "o homem", numa aparente demonstração, ou simulação, de que o ponto de vista será o de Pajão. Porém, o discurso do narrador dá lugar ao discurso do sertanejo; absorvendo suas impressões, dissolve-se nele. Podemos dizer que a narrativa tem início com a utilização do discurso indireto livre, mas remetendo à fusão do discurso do narrador com o de uma determinada personagem, que a princípio parece ser o protagonista: “(...) tinha ror de canastras e caixas, disparate de trens, quilos de dinheiro, quem sabe até ouro." (ROSA, 1967, p. 31). Não é o discurso de um narrador onisciente que percebemos nesse trecho, o discurso do narrador que alternará a voz que foca, caso contrário ele teria 
conhecimento do conteúdo da bagagem do forasteiro, não levantaria hipóteses a respeito. $\mathrm{O}$ fato é que sua onisciência está limitada à personagem que representa no momento, desligando-se da outra, vestindo de tal forma a pele daquela que assume, que o seu grau de onisciência em relação à outra arrefece. Certamente, o termo "onisciência alternada" não consta de nenhum dicionário de narratologia, mas poderia ser aplicado a esse caso particular de onisciência.

Após as primeiras linhas, em que surgem dúvidas a respeito de quem narra o conto, recebemos uma indicação de que o narrador irá incorporar uma outra personagem: "Aqui, Pajão agora o largava” (ROSA, 1967, p. 31). Largava quem, exatamente? Trata-se do narrador informando que o sertanejo largava o homem, ou o narrador informando que Pajão o deixava - o narrador - para que este assumisse a voz da outra personagem? Apesar da ambiguidade da construção, "aqui”" parece também indicar o ponto de troca. Em seguida, constatamos que não temos um único protagonista, como parecia à primeira vista, bem como tomamos conhecimento do nome deste. As indicações de personalidade de ambas as personagens estão evidentes nos dois discursos do narrador. Drepes é cauto, firme, seguro, sem medo aparente, e possui as astúcias de um homem letrado, chegando, inclusive, a ser chamado de homem cidadão, à semelhança do que menciona Riobaldo, em Grande sertão: veredas (1970), do mesmo Guimarães Rosa, modelo perseguido pelo jagunço, protagonista desse romance. Sendo o elemento estrangeiro, Drepes representa a alteridade em relação a Pajão.

Drepes entendia, porém. Deixou passar tempo, não à beira, mas cauto encostado em árvore. Deu tiro, para o alto, ao acaso. E escutou resposta: o ronco, quase a gemer, que nem surdo berro de gado. Ah, seu aleijado hospedeiro tivera manha e motivo, para o sorrisão com caretas! Sim - serpente gigante ali se estava, saída de sob a água, sob fôlhas. Drepes ia esperar, trepado à árvore, havia a ver. (ROSA, 1967, p. 31).

Pajão, por sua vez, é descrito como esquerdo, duro, aleijado, coxeando ou caranguejando, "estragando muito espaço", numa casa que fedia a couros podres. Ele não olha nos olhos e seu ódio se derrama pelos cantos. Tem a boca retorcida, vive a materialidade. Sertanejo meio metamorfoseado em cobra, pois que incorpora as características do réptil, Pajão não aceita que o homem urbano venha invadir o seu território, se imiscuir no que não lhe diz respeito, querendo aprender as coisas

3 A partir da tipologia de Norman Friedman, "onisciência seletiva", criamos a ideia de "onisciência alternada", já que são apenas duas as consciências entre as quais se alterna o narrador. Essa alternância de uma consciência à outra cria o efeito ou a ilusão do ondular da cobra que, dessa forma pode ser "vista" atravessando a narrativa (Cf. LEITE, 1997). 
que só ele e os do seu lugar têm o direito de saber, como o conhecimento acerca da vida animal da região, mais especificamente sobre a sucuri, espécie de lenda, mito. Por esse motivo, a recepção ao forasteiro é hostil:

O terrível homem cidadão, azougado da cabeça, xê, pensando ferros e vermelhos. Não deixava mão da carabina e revólver, por entre o engenho de suas trenheiras malditas. A êle a gente tinha de responder, ver ensinar o que vige no desmando, nhão, as outras coisas da natureza. (ROSA, 1967, p. 32).

Porém, são dois pontos de vista. O narrador, quando incorporado a uma personagem, adota a visão de mundo desta. Por exemplo, quem julga Pajão como um ogro, ser mais que primitivo, ligado às coisas do mal, quem o vê com determinadas características diabólicas, é Drepes, malgrado a intermediação do narrador que, de qualquer forma, parece adotar o ponto de vista deste como válido. É uma tendência natural, já que o discurso de ambos, mais erudito, aproxima-os. Essa tomada de posição por parte daquele que narra pode, de certa forma, influir no julgamento do leitor: "Aquêle rude ente, incompleto, que sapejava, se arrimando às paredes do casebre, no andar defeituoso, de tamanduá, já pronto para pesadelo." (ROSA, 1967, p. 33).

Pajão, com certeza, não se vê de tal forma; ao contrário, julga que o invasor, e seus "trens" desconhecidos, é que têm algo de diabólico. Ambos se referem a Deus, mas o que esses discursos realmente dizem passa longe do conteúdo religioso. Pajão poderia ser visto apenas como um habitante do interior, algo arredio e desconfiado, com certa possessividade em relação a seu território e às coisas do seu imaginário. O que julga ser seu direito, não quer dividir com o homem da cidade, pois este, segundo sua lógica, já possui muitas outras coisas, às quais ele sequer tem acesso. Trata-se de uma questão de justiça, intui o sertanejo. E, não querendo compartilhar, sonega informações: “'Sucruiú? Aqui nunca divulguei...” (ROSA, 1967, p. 31).

Mas o homem civilizado quer penetrar no mundo do outro, quer saber das coisas desse mundo para ele desconhecido, saber da cobra-grande e, nesse intuito, irá utilizar suas armas: suas tecnologias - cujos nomes Pajão desconhece -, seu estudo e, acima de tudo, sua palavra treinada. Fazendo-se desentendido de todo, indaga sobre a forma de ataque da sucuri ${ }^{4}$ a sua presa, provocando o "adversário", atiçando-lhe os brios, induzindo-o a falar, incitando-lhe, avançando sempre um passo, infiltrando-se gradativamente: “-'Ela morde a presa, mas fica com o rabo

4 Irene Gilberto Simões extrai do texto a sequência de questões. Observando-as em separado, identifica nesses enunciados, colocados paralelamente, a imagem do ataque da cobra (Cf. SIMÕES, 1976, p. 93-96). 
enganchado num pau? Se aquela corre, larga-lhe trela, estirada, afinada, depois repuxa e mata, tomando-lhe o fôlego das ventas?' - Drepes insistia." (ROSA, 1967, p. 31). Pajão tenta desconversar: “-‘O senhor está dizendo. '” (ROSA, 1967, p. 32). Além disso, nesse ponto da narrativa, encontramos uma outra construção que cria efeito ambíguo. Trata-se da utilização de "a gente". Utilizada, aqui, em três ocasiões, em cada uma delas podemos perceber uma tendência diferente. $\mathrm{Na}$ primeira delas, seu uso parece ser dos mais convencionais: "a gente" podendo ser traduzido por "nós", em sua forma generalizante: "A êle a gente tinha de responder..." (ROSA, 1967, p. 32). Porém, ainda restam dúvidas, pois o contexto mais exatamente o parágrafo anterior do texto - favorece essa situação. A expressão pode remeter a "eles" - a gente de Pajão. Pela evolução do que podemos chamar de diálogo percebemos que, primeiro, Drepes pergunta ao sertanejo a respeito da sucuri. Este responde que naquelas paragens nunca a havia "divulgado". Drepes insiste, indagando sobre a forma de ataque da sucuri, descrevendo de forma bizarra como supõe - ou finge supor - esse ataque. Novamente Pajão foge do assunto, sem responder precisamente. A seguir, o trecho que confunde de tal forma as vozes que não sabemos a qual consciência pertence: "O candeeiro era para Drepes, no apertado quarto, sua fortaleza. - 'Você já viu sucuri?!' Acolá, no escuro, os do Pajão, a família, não se movesse” (ROSA, 1967, p. 32).

À primeira vista estamos sob o ponto de vista de Drepes, que estaria reiterando a pergunta feita a Pajão. Acontece que, pontuando a questão formulada, temos um ponto de exclamação acompanhando o ponto de interrogação, o que remete à consciência do sertanejo, indignado com a insistência do visitante. Tal fórmula se repete três parágrafos adiante, embora sem o ponto de exclamação, quando aquele repete para si mesmo a indagação do outro, sobre se a cobra pegaria/comeria homem. Portanto, a questão não parece ser uma reformulação daquela que foi posta anteriormente por Drepes, mesmo porque, a resposta, negativa já havia sido fornecida a ele. Talvez a indagação pudesse estar sendo feita, dessa vez, à gente de Pajão, o que justificaria o próximo emprego de "a gente", no texto, como referente não a "nós", mas a "eles". Da conclusão a que chegarmos a respeito do primeiro emprego da expressão é que dependerão os rumos de interpretação decorrentes de sua próxima ocorrência, bem como a definição a respeito de quem responde à pergunta formulada: “- a gente emendava." (ROSA, 1967, p. 32). Se optarmos por atribuir a questão a Drepes, insistente, ele estaria recorrendo à "gente" de Pajão, já que não obteve uma resposta objetiva deste. Dessa forma, a resposta que o visitante recebe também partiria dos familiares de seu hospedeiro. Caso contrário, se a opção for por uma repetição interior da pergunta pelo sertanejo, "a gente”, então, poderia 
ser traduzido por "nós", ele e "toda a gente", de forma geral. O que parece ser o mais provável, pois já pudemos, anteriormente, constatar que os familiares de Pajão não costumam responder ao que se lhes pergunte, preferindo encaminhar o emissor da questão ao patriarca. Porém, é o terceiro emprego da expressão o responsável pela maior ambiguidade, muito embora a pontuação, no trecho correspondente, desempenhe um papel ainda mais marcante para a ocorrência desse efeito.

Aquêle homem zureta, atentado! Agora dava corda no relógio sem números nem ponteiros, a gente escutava: a voz guardada dêle mesmo, Pajão, depondo relato... (ROSA, 1967, p. 32).

Duas hipóteses podem ser formuladas. A substituição de uma das vírgulas por um ponto final no trecho "[...], a gente escutava: a voz guardada dele mesmo," resolveria o problema, acabaria com a ambiguidade e poderíamos precisar o referente de "a gente". Se optarmos por substituir a primeira vírgula, "a gente", seriam Drepes e os outros, que ouviriam Pajão, "a voz guardada dele mesmo, depondo relato" ou, passar a informação, indiretamente, ao visitante. Caso a opção seja pela substituição da segunda vírgula, "a gente" seriam Pajão e os outros escutando Drepes, silencioso, "a voz guardada dele mesmo", dar corda ao tal relógio sem números nem ponteiros, enquanto Pajão "depõe relato", também aqui de forma indireta. A segunda hipótese parece ser a mais provável. De qualquer forma, e o que é melhor, o autor optou por não nos dar certeza alguma, convidandonos a jogar, brincar com as possibilidades do texto, fruí-lo. ${ }^{5}$ Ainda no mesmo trecho do conto, há outra ocorrência ambígua proporcionada pelo vocábulo "atentado!", que tanto pode significar atenção quanto remeter a tentação.

$\mathrm{Na}$ sequência dessa luta de classes velada do conto, Drepes, com alguma informação, arrisca mais um passo: “" - Pega homem?’” (ROSA, 1967, p. 32), o que faz com que seu anfitrião se sinta ofendido. Pajão inveja a astúcia, a segurança, o saber e os apetrechos de seu hóspede que, também bastante desconfiado, mas tentando não demonstrar, se antecipa às intenções daquele que tem como primitivo e desconhecido. Tão primitivo que, ao contrário do que seria lógico e usual, coloca o animal hierarquicamente acima do homem ou, ainda, daquele homem especificamente, numa tentativa de marcar sua posição como superior a dele: "Voltaram, cão e homem." (ROSA, 1967, p. 32).

Tanto Drepes quanto Pajão sabem que estão em guerra não declarada verbalmente, que seria mais uma disputa entre os dois mundos antagônicos que representam. Perpassa a narrativa uma ameaça velada, o dito impregnado do não-dito, que se 
lê nas reticências e entrelinhas. A palavra não pronunciada diz mais do que aquilo que se enuncia. É uma atmosfera hostil, repleta de subterfúgios, falsa cordialidade e tensão. Reforçando essa atmosfera, a ameaça do bicho, ancestral, terrível, traiçoeiro e invisível. Essa ameaça velada se dá, sobretudo, no nível do discurso, em que se evidencia o ataque indireto ao discurso do outro pelas personagens, configurando o que Mikhail Bakhtin denomina "polêmica interna velada" (BAKHTIN, 2002b), uma entre outras formas de bivocalidade encontradas em "Como ataca a sucuri".

Cada uma das personagens tenta adivinhar qual será a próxima jogada ou estratégia do inimigo. Drepes, o invasor, se vale de suas armas, da luz do candeeiro, de seus meios tecnológicos, ou supostos, como, por exemplo, o pó que espalha na comida e na água, dizendo ser um indicador do quanto a comida está sã, e que provavelmente não passa de farinha ou algo tão inofensivo quanto. O mesmo se dá com o telefone, que não passa de uma caixa com fios. O forasteiro é hábil na arte do blefe: "No prato de comer, esparziu pitada de um pó branco: - 'Instrui de qualquer veneno: formicida, feitiço, vidro moído. Tendo, o remédio fica azul...' - falou, aquilo ainda oferecendo." (ROSA, 1967, p. 32).

Pajão se apega a seus conhecimentos acerca do local, afinal de contas a batalha se dá em seus domínios, e essa é sua principal arma: o saber ancestral. Porém, subestima o adversário, supondo que do local ele nada saiba:

Pajão agora o largava, ao pé do poço oculto, quieto conforme ele mesmo influído pedira. Ife! Pescasse. Entendia o mundo de mato, usos, estes ribeirões de águas cinzentas?

Drepes entendia, porém. (ROSA, 1967, p. 31).

Mas é a palavra que estabelece as regras, usada como forma de poder. Provavelmente de maneira intuitiva, Pajão também tem conhecimento disso, a tal ponto que ele é o único que fala em sua família. Porém, trata-se, aqui, de quem tem a palavra mais afiada. Portanto, Drepes está em vantagem. Não são as "trenheiras" do invasor que fazem a diferença, estas são usadas como matéria de blefe. O sertanejo julga que são essenciais, pois desconhece o que não é natural. Ignorando o nome, julga que são coisas do demo: "Delatava a êle o caminho uma caixeta redonda, que tinha, boceta de herege.” (ROSA, 1967, p. 32). Mesmo o vocábulo empregado - "delatava" - já indica o juízo que faz a respeito. De qualquer forma, intui que não são apenas esses apetrechos que o colocam em desvantagem, já que reconhece a astúcia do adversário: "Mas o danado levara também o Pacamã, cachorro sério, decerto por trapaça cedia a êle parte da matula, farinha e carne..." (ROSA, 1967, p. $32)$. 
Pajão sonega informações e, quando não mais consegue fazê-lo, tenta usar seu conhecimento acerca das coisas da natureza a seu serviço, com o intuito de amedrontar Drepes. E é como se não falasse apenas da cobra, mas dele próprio. Isso ele faz, "a voz guardada dele mesmo, Pajão, depondo relato" (ROSA, 1967, p. 32), não diretamente ao forasteiro. Este recebe como entrega e não como ameaça as palavras de seu adversário. Constatando que estão próximas da realidade, "aprova a desfábula" (ROSA, 1967, p. 33):

- 'Sucruiú agride de açoite, feito o relâmpago, pula inteira no outro bicho... Aquilo é um abalo! Um vê: ela já ferrou dente e enrolou no outro o laço de suas voltas, as duas ou três rôscas, zasco-tasco, no soforçoso... o bicho nem grita, mal careteia, debate as pernas de trás, o apêrto tirou dêle o ar dos bofes. Sucruiú sabe o prazo, que é só para sufocar, tifetrije... Ai, solta as laçadas de em redor do bicho morto, que ela tateia todo, com a linguazinha. Começa a engolir... (ROSA, 1967, p. 32-33).

Pajão tenta um último golpe, artimanha, misto de ameaça física e blefe. Dá o cavalo e o burro do hóspede como fugidos, quando este tenta partir, cercando-se dos seus, armados. Querem-no espécie de prisioneiro. Mas nesse terreno o sertanejo não é hábil, ao contrário de seu opositor que, malgrado o medo, que disfarça, usa da palavra e de seus apetrechos para vencer seu hospedeiro. Vence, mas não ganha seu respeito, ainda, o que virá a acontecer no final, quando derrota o adversário onde este tem o domínio: na natureza. Matando a sucuri (que aqui ganha a denominação de sucuriju), Drepes sobrepuja o adversário, que assim o reconhece, contrafeito, prestando-lhe reverência, ao mesmo tempo em que avança sobre os despojos do bicho morto: “- 'Acho razão no senhor...”' (ROSA, 1967, p. 33).

O discurso predominante em "Como ataca a sucuri" é o indireto livre, mas o autor utiliza também outras formas de transmissão do discurso citado, como o discurso direto preparado pelo indireto livre, emergindo deste, colocado entre aspas. A esse respeito, cabe destacar que a forma direta aparece precedida de travessão, mas colocada antes das aspas, o que torna evidente a interferência do discurso do narrador, deixando claro que estamos diante de um enunciado que, apesar de direto, é citado, passa pelo crivo de um narrador, situado fora da narrativa:

À noitinha, um dos filhos de Pajão o veio buscar; taciturno, bronco, só matéria e eventual maldade. - 'De que jeito é que sucuri pega capivara?' - Drepes indagou, curioso, irônico. (ROSA, 1967, p. $31)$. 
Tal recurso estabelece estranhas relações discursivas, revelando um discurso que é direto, mas citado pelo discurso de um narrador, o qual incorpora as personagens em toda a sua especificidade: tanto sua personalidade, quanto sua linguagem e, ainda, sua forma de colocar-se no mundo, o que não deixa de ser, também, linguagem. O narrador está situado a meio caminho entre uma e outra personagem, mas parece mais próximo de Drepes. Podemos detectar uma sutil tomada de partido do narrador, privilegiando a personagem do forasteiro.

A situação de discurso, nesse conto, segue uma orientação pictórica, pois que é caracterizado por formas mistas de transmissão do discurso citado, o que engloba tanto o discurso direto, quanto o indireto e o indireto livre, além de suas nuanças. Colocado entre aspas, o discurso direto se amalgama ao indireto que, livre ou não, faz com que a forma de apreensão e transmissão do discurso do outro não deixe de ser analítica. O fato é que o discurso de Pajão, a ser citado pelo narrador, é resistente à penetração pelo discurso deste, o que faz com que haja dificuldade de apagamento das fronteiras entre eles, tanto que é o narrador que acaba por incorporar o discurso da personagem. Essa resistência não se dá em razão do discurso a ser citado ser reconhecido como superior hierarquicamente, mas pela sua especificidade, porque se caracteriza como enunciação de outrem em um todo uno, impenetrável, imune a transformações, razão pela qual o autor opta por conservar o discurso direto das personagens - no caso de Drepes, para obtenção do efeito "serpenteante" pretendido - sem abrir mão do filtro proporcionado pelo narrador em terceira pessoa, o contador do causo acontecido e, sobretudo, recurso unificador das linguagens e dos mundos representados. O narrador, aqui, é uma necessidade, devido à impossibilidade de troca linguística existente entre as personagens.

Interessante destacar que, por ser apresentada dessa forma - com a passagem do discurso direto para o indireto conservando os índices de autoria do discurso do outro -, a situação discursiva não caracteriza uma inadequação estilística, pois acaba ficando mais próxima de uma outra variante, que é a do discurso indireto analisador da expressão, com interferências de discurso, onde o foco está também no falante. Cabe salientar que discurso direto, aqui, não o é exatamente; tratase, praticamente, de uma simulação, já que existe uma análise da expressão nesse discurso - característica do indireto -, mesmo que seja uma forma externa. Confundindo-se com o indireto livre, é forma mais que híbrida, proporcionando uma análise da expressão em alto grau. O estranhamento que a forma utilizada para a transmissão do discurso de outrem causaria não ocorre, pois esse efeito é intencional. As personagens têm direito à voz narrativa, intermediada, mas não 
à fala direta, apenas têm seu discurso citado, e em mais de uma forma, inclusive numa forma aparente de discurso direto. Além disso, o discurso próprio do narrador fica um pouco camuflado no discurso citado. Em alguns momentos, há dificuldade em estabelecer quem fala ou, mais especificamente, onde começa a fala de um e termina a de outro.

O recurso utilizado dá conta, também, da impossibilidade de troca linguística, por isso a presença desse narrador específico. E, não havendo essa possibilidade de diálogo, ou ela existindo de forma tosca, primitiva, a comunicação entre locutor e interlocutor efetiva-se apenas num outro nível, a partir de outros signos - não verbais inclusive -, outros instrumentos semióticos - gestos, sons, olhares, etc. :

O terrível homem cidadão azougado da cabeça, xê, pensando ferros e vermelhos. Não deixava mão da carabina e revólver, por entre o engenho de suas trenheiras malditas [...] (ROSA, 1967, p. 32).

Pajão cravando-lhe os olhos, como dentes, - tendo em volta os três filhos ameaçadores. (ROSA, 1967, p. 33).

Portanto, temos um narrador em terceira pessoa com uma simulação de primeira pessoa, intermediada por esse narrador, que faz com que a voz de ambos os protagonistas se faça ouvir, em toda a sua diversidade, como no discurso direto, traduzindo cada uma das personagens em sua própria linguagem, hábitos, sensações, reações e pensamentos. Esse recurso torna mais viva a situação de fala e presentifica a ação, formando um sofisticado jogo polifônico. As ideologias são conflitantes e representadas pela voz das personagens que, independente da mediação do narrador, se fazem ouvir. Estamos diante de uma narrativa polifônica, em vários níveis, e plurilíngue - mais bilíngue, nesse caso -, sendo que o plurilinguismo é introduzido via discurso das personagens, sem efeito paródico, no entanto. Podemos dizer, ainda, que o conto em questão não pertence totalmente a um gênero específico, pois apesar de pertencer de forma geral ao gênero narrativo, observamos que ele incorpora as características de outros gêneros, ou de um grupo especial de gêneros, marcadamente aqueles ligados às formas populares do contar, o que nos leva a identificar o plurilinguismo introduzido, também, via gêneros intercalados. Os protagonistas não podem interagir, pois representam mundos antagônicos. Portanto, o grau de onisciência do narrador resolve essa questão, dando por vezes a impressão de que temos dois narradores em terceira pessoa, tal a alternância de uma consciência à outra, numa assimilação do código linguístico das variantes sociais dos falantes. A própria denominação da cobra grande é dúplice: enquanto Drepes fala em "sucuri", a exemplo do narrador, no título do conto, Pajão faz uso da forma local, "sucruiú", ou "sucuriju", utilizada no final 
da narrativa. Essa alternância de consciência é recurso que, associado a outros de estilo, fazem com que a sucuri possa se materializar, cortando, serpenteando pela narrativa, configurando uma espécie de metamorfose, que nesse caso é mais uma ilusão de ótica, efeito de prestidigitação, efetivado pela linguagem. É no nível do discurso que se dá esse efeito. A sucuri, pressentida ao longo da narrativa, é mais que metáfora da violência latente que subjaz ao texto em seu todo, é também presença, de certa forma concreta, "vista" em todo o seu ondular, pela terceira pessoa que o texto leva em conta, o próprio leitor.

Em “Como ataca a sucuri”, temos a impressão de conto compilado da oralidade, sobretudo pela sugestão da temática, mas o narrador não é um contador de estórias, no sentido estrito do termo, pois os esquemas utilizados na sua estruturação e caracterização não permitem que assim seja. Além disso, ele não participou dos fatos narrados, não é personagem - fato que dá credibilidade a um contador de estórias -, nem tampouco se dirige a um interlocutor, presente ou sugerido, no interior da narrativa. O que constatamos é um aproveitamento das inúmeras possibilidades que os esquemas proporcionam, como as formas utilizadas na transmissão do discurso citado, principalmente, apesar de o autor recorrer, também, a fórmulas arcaicas de discurso, como aquelas observadas em La Fontaine que, segundo Gertraud Lerch, citada por Bakhtin, eram utilizadas por uma questão de insuficiência gramatical, o que acabaria favorecendo o surgimento do discurso indireto livre. Em Guimarães Rosa não há o caso de insuficiência gramatical, evidentemente, mas sim a intenção deliberada de, apropriando-se da matéria popular, imitá-la ou atualizá-la. O autor busca a estrutura, a forma, os conteúdos e os temas do conto popular, sem abrir mão dos recursos, contemporâneos ou não, da linguagem. Esses recursos, através do seu trabalho, fazem com que o conto popular - anedótico, maravilhoso, conto de fadas, etc. - transcenda a sua condição e atinja elevado grau artístico. É justamente esse aproveitamento de fórmulas já em desuso, associadas aos modernos recursos de estilo, que fazem de Guimarães Rosa um atualizador do conto popular. A atualização da forma se dá, aqui, sem perdas, sua modernidade está no trabalho com a linguagem. A espécie de metamorfose que observamos ou, nesse caso, a visualização do animal - vivo, pelo menos - se faz, igualmente, no nível da linguagem pois, sendo uma atualização, a cobra não pode se materializar. $\mathrm{O}$ animal lendário, no conto literário, não pode aparecer, como a Mboitatá ${ }^{6}$ ou a Cobra Norato, por exemplo, que são personagens de lendas do folclore brasileiro.

6 Mboitatá, a cobra de fogo. Lenda popular na região sul do Brasil. 
Tutaméia é uma das obras mais enigmáticas de Guimarães Rosa. Os estudiosos, em sua maior parte, veem-na como a síntese da poética rosiana, que nela atinge seu auge, e como explicação da sua forma de fazer literário, codificada em seus quatro prefácios. Mary L. Daniel, por exemplo, afirma que "Tutaméia surge como uma benção na sua carreira literária. [...] constitui a afirmação definitiva da obra rosiana" (DANIEL, 1968, p. 178). Lívia Ferreira Santos considera Tutaméia o livro-testamento de Guimarães Rosa, acrescentando que "[...] a organização do material linguístico alcança o mais alto grau de singularidade com referência à norma comum" (SANTOS, 1983, p. 536). Mas há os que a têm como obra de certa forma menor ${ }^{7}$, ou simples reunião de contos que se apresentam sintéticos e objetivos em virtude da especificidade de seu surgimento e publicação - foram publicados em revistas e, devido a este fato, deveriam ser apresentados de forma condensada ${ }^{8}$. Há, também, aqueles que rejeitam o "mapa" da obra, como algo que não deveria ser fornecido, pois que configuraria uma traição do autor a seu público. Segundo Paulo Ronái, no posfácio a Tutaméia (se assim pode ser chamado, já que se apresenta antes do seu índice "de releitura")9", o próprio Guimarães tinha essa obra como da maior importância, surgida

em seu espírito como um todo perfeito não obstante o que os contos necessariamente tivessem de fragmentário. Entre estes havia interrelações as mais substanciais, as palavras todas eram medidas, postas no seu exato lugar, não se podendo suprimir ou alterar mais de duas ou três em todo o livro sem desequilibrar o conjunto. (RONÁI, 1967, p. 216).

Benedito Nunes trata as quarenta narrativas de Tutaméia como "casos exemplares, a modo de diversa figuração de grande fábula ou mito" (NUNES, 1976, p. 203). Diz, ainda, que

de fato, o jogo da linguagem, levado, em Tutaméia, ao extremo do paradoxo, volteia nas diversas glosas humorísticas a expressões comuns, e num confronto exaustivo com o mundo e com a existência expande-se na criação de vocábulos novos. Foi a dúvida, a tudo problematizando, que impulsionou esse jogo e que o conduziu

7 Como Lenira Marques Covizzi, que afirma ser Tutaméia o segundo passo (o primeiro seria Primeiras estórias) no caminho de volta da ficção rosiana (Cf. COVIZZI, 1978, p. 84).

8 Segundo Paulo Ronái, os contos de Tutaméia constituem-se em romances em potencial, comprimidos ao máximo, dotados de carga explosiva (Cf. RONÁI, 1985, p. 22).

9 No caso da $9^{a}$ edição, de 1985, pela editora Nova Fronteira. A primeira edição, de 1967, pela editora José Olympio, não traz o texto de Paulo Ronái, portanto não há essa "invasão" à estrutura da obra. 
àqueles últimos limites, onde a linguagem se transforma em meio de revelação, para dizer o que antes não podia ser dito. (NUNES, 1976, p. 209).

O certo é que a obra segue sendo menos estudada do que as demais. Não são tantas as análises voltadas a seus contos, a exceção de alguns, como "Desenredo", por exemplo. $\mathrm{O}$ enigma permanece, ainda, por ser revelado.

\begin{abstract}
This study discusses some issues concerning the genesis of the short story, as well as the opposition between simple form and artistic form. We take Guimarães Rosa as a paradigm, because in his work the author rescues aspects related to ancestral ways of telling, by updating them. As a storyteller, with the use of themes and popular forms, characteristics of the narratives of oral tradition, which often use the wonderful element, the author weaves his own way of telling stories. His style, however, does not resemble the compilers', thanks to a meticulous work with the word, which ends up attributing to the text a specificity that intrigues and invites to the game. We study this updating of the popular narrative of oral tradition in the work of Guimarães Rosa in the light of Bakhtin's Metalinguistic. For such, we use the short story "Como ataca a sucuri", published in Tutaméia, as an example of this fact, as we believe that his theory helps to clarify aspects of Rosa's work concerning the discourse. The direction of our analysis refers precisely to the discourse in Rosa's work, especially to the ways it is cited, which is a relevant factor in his literary work.
\end{abstract}

Keywords: Short story. Orality. Guimarães Rosa. Philosophy of Language

\title{
Referências
}

ANDRADE, Mário de. Contos e contistas. In: O empalhador de passarinhos. 3. ed. São Paulo: Martins; Brasília: INL, 1972.

AUBRIT, Jean-Pierre. Les fondateurs: du Décaméron à l'Heptameron. XIXe Siècle: le siècle des maîtres. In: Le conte e la nouvelle. Paris: Armand Colin, 1997. 
BAKHTIN, Mikhail. Marxismo e filosofia da linguagem. 9. ed. São Paulo: Hucitec/Anna Blumme, 2002a.

BAKHTIN, Mikhail. Problemas da poética de Dostoievski. 3. ed. Rio de Janeiro: Forense Universitária, 2002b.

BARTHES, Roland. O prazer do texto. 4. ed. São Paulo: Perspectiva, 2004.

CORTÁZAR, Julio. Alguns aspectos do conto. Do conto breve e seus arredores. In: Valise de Cronópio. 2. ed. São Paulo: Perspectiva, 1993.

COVIZZI, Lenira Marques. O insólito em Guimarães Rosa e Borges. São Paulo: Ática, 1978.

DANIEL, Mary Lou. João Guimarães Rosa: Travessia literária. Rio de Janeiro: Livraria José Olympio Editora, 1968.

FRIEDMAN, Norman. apud., LEITE, Lígia Chiappini Moraes. O foco narrativo. 8. ed. São Paulo: Ática, 1997.

JOLLES, André. O Conto. In: JOLLES, André. Formas simples. São Paulo: Cultrix, 1976.

LEITE, Ligia Chiappini Moraes. Foco narrativo. São Paulo, Ática, 1997.

LIMA, Herman. Evolução do conto. In: COUTINHO, Afrânio. (Org.) A Literatura no Brasil. Rio de Janeiro: Sul-Americana, 1971.

LINARES, Luis Barrera. Apuntes para una teoría del cuento. In: PACHECO, Carlos y LINARES, Luis B. (Org.) Del cuento y sus alrededores - aproximaciones a una teoría del cuento. 2. ed. Caracas: Monte Ávila, 1997.

MATTHEWS, Brander. La filosofia del cuento. In: PACHECO, Carlos y LINARES, Luis B. (Org.) Del cuento y sus alrededores - aproximaciones a una teoría del cuento. 2. ed. Caracas: Monte Ávila, 1997.

NUNES, Benedito. Tutaméia. In: O dorso do tigre. São Paulo: Perspectiva, 1976.

PERRAULT, Charles. apud., JOLLES, André. O Conto. In: Formas simples. São Paulo: Cultrix, 1976.

PIGLIA, Ricardo. Teses sobre o conto. In: Revista brasileira de Literatura Comparada, n. 1, mar. 1991.

POE, Edgar Allan. A primeira teoria do conto. (Resenha a Twice told tales, de N. Hawthorne). A filosofia da composição. In: Poemas e ensaios. Rio de Janeiro: Globo, 1985. 
RONAI, Paulo. Prefácio a Tutaméia. In: ROSA, João Guimarães Rosa. Tutaméia. Rio de Janeiro: José Olympio, 1967a.

RONAI, Paulo. Prefácio a Primeiras estórias. In: ROSA, João Guimarães. Primeiras estórias. 3. ed. Rio de Janeiro: José Olympio, 1967b.

ROSA, Guimarães João. Corpo de baile. 2. ed. Rio de Janeiro: José Olympio, 1960.

ROSA, Guimarães João. Tutaméia. Rio de Janeiro: Nova Fronteira, 1967.

ROSA, Guimarães João. Tutaméia. 9. ed. Rio de Janeiro: Nova Fronteira, 1985.

ROSA, Guimarães João. Grande sertão: veredas. 7. ed. Rio de Janeiro: José Olympio, 1970.

SANTOS, Lívia Ferreira. A desconstrução em Tutaméia. In: COUTINHO, Eduardo de Faria (Org.) João Guimarães Rosa. Rio de Janeiro: Civilização Brasileira, 1983, V. 6.

SIMÕES, Irene Jeanete Gilberto. Guimarães Rosa: as paragens mágicas. São Paulo: Perspectiva, 1976.

SIMONSEN, Michèle. Conto popular e folclore. In: O conto popular. São Paulo: Martins Fontes, 1987.

WIELAND, Christoph Martin apud JOLLES, André. O Conto. In: JOLLES, André. Formas simples. São Paulo: Cultrix, 1976.

Submetido em: 15 de junho de 2015. Aceito para publicação em: 09 de outubbro de 2015. 